\title{
KAJIAN KONSEPTUAL PEMODELAN PERUBAHAN PENGGUNAAN LAHAN UNTUK STUDI ILMU LINGKUNGAN
}

\author{
Bokiraiya Latuamury \\ Fakultas Kehutanan Universitas Pattimura-Ambon \\ Email: okky.environmentalscience@gmail.com
}

\begin{abstract}
Modeling is one of the methods in the portfolio of techniques and approaches available to unravel the dynamics of the land-use system. In this perspective, models are used as a learning and communication tool between researchers to formalize knowledge on the dynamics of land-use change. Land-use system is a very complex system, such that computer modeling is needed as a computational laboratory to estimate and test hypotheses about the process oflanduse change. One of the major difficulties in multi-disciplinary research is to find ways to express oneself, which are acceptable to all the disciplines involved and free from the connotation of any or all of them. Land-use change models play an important role in exploring possible future developments in the land-use system. This paper attempts to show the methods and approaches to be used as a communication and learning environment for stakeholders involved in the decision making about land-use change systems in the field of environment.
\end{abstract}

Keyword:Modeling, Land-Use Change, Environmental Science

\begin{abstract}
ABSTRAK
Pemodelan adalah salah satu metode dalam teknik portofolio sistem perubahan penggunaan lahan dan berguna untuk mengungkapkan dinamika sistem penggunaan lahan. Pada perspektif ini, model berguna sebagai alat pembelajaran dan alat komunikasi antar- peneliti dalam pengetahuan formal mengenai dinamika perubahan penggunaan lahan. Sistem penggunaan lahan merupakan sistem yang sangat kompleks, sehingga pemodelan komputer diperlukan sebagai laboratorium komputasi untuk menduga dan menguji hipotesis mengenai proses perubahan penggunaan lahan. Salah satu kesulitan utama dari sains murni dalam penelitian perubahan penggunaan lahan adalah untuk menemukan cara yang dapat menjembatani semua disiplin ilmu yang terlibat, dapat diterima, dan bebas dari kooptasi semua komponen yang terlibat dalam model. Model-model perubahan penggunaan lahan berperan penting dalam mengungkapkan fenomena dan ide-ide mengenai cara-cara yang dapat dipahami bagi praktisi di berbagai disiplin ilmu. Tulisan ini mencoba menampilkan metode dan pendekatan yang berkaitan dengan sistem perubahan penggunaan lahan sebagai bahan pembelajaran di bidang lingkungan.
\end{abstract}

Keywords: Pemodelan, Perubahan Penggunaan Lahan, Ilmu Lingkungan. 


\section{PENGANTAR}

Pendekatan model berkaitan dengan sejumlah aspek penting dari sistem penggunaan lahan, guna memahami faktorfaktor penentu hubungan fungsional dari perubahan penggunaan lahan. Faktor penentu hubungan fungsional tersebut meliputi faktor biofisik, ekonomi, sosial, budaya, politik, dan kelembagaan. Kemajuan penting telah dibuat pada aspekaspek yang berbeda, dan merupakan bagian dari siklus pemodelan, meliputi (a) bidang validasi model, (b) pendekatan partisipatif untuk mengembangkan skenario alur pemodelan, (c) interaksi antara dampak biofisik dan sosial-ekonomi, dan (d) hubungan antara pola berbasis proses, dan berdasarkan deskripsi faktor pendorong perubahan penggunaan lahan.

Kesenjangan dalam sains perubahan penggunaan lahan terlihat jelas selama proses membangun model (Lambin et al:2000). Proses membangun model didasarkan atas pola dan kepekaan dari determinan-determinan kunci yang diuji. Kepekaan analisis berguna dalam mengidentifikasi mekanisme perubahan penting di suatu daerah, yang tidak dapat diidentifikasi dari pengamatan lapangan. Sebagai alat pembelajaran dalam mengungkap faktor pendorong dan dinamika sistem perubahan penggunaan lahan, model perubahan penggunaan lahan berperan penting dalam mengeksplorasi perkembangan sistem penggunaan lahan masa depan. Sistem fungsional dari model perubahan penggunaan lahan dapat digali melalui skenario dan visualisasi konfigurasi penggunaan lahan, sehingga menghasilkan keputusan kebijakan dan perkembangan sistem penggunaan lahan. Eksplorasi dan kapasitas proyektif, memungkinkan model penggunaan lahan dapat digunakan sebagai alat komunikasi dan pembelajaran lingkungan bagi para pemangku kepentingan- (stakeholder). Proyeksi model perubahan penggunaan lahan digunakan sebagai sistem peringatan dini terhadap dampak perubahan penggunaan lahan di masa depan, dan hotspot untuk bidang-bidang prioritas dalam analisis atau intervensi kebijakan lingkungan.

Diversifikasi pendekatan pemodelan perubahan penggunaan lahan berkembang pesat selama beberapa tahun terakhir. Hal ini menantang para peneliti di berbagai bidang ilmu untuk mereview dan mengklasifikasi pendekatan-pendekatan model yang berbeda. Sistem klasifikasi sebagian besar didasarkan pada proses perubahan penggunaan lahan yang dominan, ditangani oleh model, dan teknik simulasi berdasarkan teori yang mendasarinya. Lambin (1997), memberikan gambaran umum pemodelan deforestasi, sementara Kaimowitz dan Angelsen (1998) fokus pada model deforestasi berdasarkan teori ekonomi. Sejumlah hasil penelitian pemodelan perubahan penggunaan lahan di berbagai bidang kehidupan manusia, antara lain : U.S. EPA (2000) menyajikan tinjauan model perkotaan terpadu, Parker et al., (2003) dan Bousquet dan Le Page (2004) memberikan ikhtisar pendekatan pemodelan multi-agen. Lambin et al.,(2000) mereview model untuk intensifikasi pertanian, dan Bockstael dan Irwin (2000) mereview sejumlah model penggunaan lahan berlandaskan pada teori ekonomi. Agarwal et al., (2001) mereview 19 model berdasarkan kondisi spasialnya, sementara Briassoulis, (2000) memilih mereview kompleksitas aktivitas manusia, dan Verburg et al., (2004) memberikan ikhtisar model penggunaan lahan yang luas.

\section{HASIL DAN PEMBAHASAN Model Spasial dan Model Non-Spasial}

Tipe-tipe model perubahan penggunaan lahan perlu dibedakan dalam proses membangun model, terutama membedakan antara model spasial dan model non-spasial. Perbedaan ini penting ketika memilih tipe 
model untuk aplikasi tertentu, yang sangat menentukan jenis pertanyaan penelitian dalam menjawab aplikasi tertentu. Model spasial bertujuan untuk merepresentasi perubahan penggunaan lahan eksplisit secara spasial pada skala spasial secara detail, di mana perubahan penggunaan lahan mengindikasikan piksel tunggal dalam entitas raster atau komponen spasial seperti unit administratif. Kelompok model ini, dapat mengeksplorasi variasi spasial dalam perhitungan perubahan penggunaan lahan dan perhitungan perubahan biofisik lingkungan dan sosial masyarakat Beberapa contoh model spasial terkenal adalah Model CLUE (The Conversion of Land Use and its Effects), model SLEUTH dan model GEOMOD (Pontius et al., 2001; Verburg et al., 2002).

Sementara kelompok model nonspasial fokus terhadap pemodelan atas laju dan besaran perubahan penggunaan lahan tanpa perhatian spesifik terhadap distribusi spasial. Contohnya, Model SALU (model untuk wilayah Sahel) disajikan oleh Stéphenne dan Lambin (2001). Evans et al., (2001) menyajikan model non-spasial untuk deforestasi di Altamira di bagian wilayah Amazon. Bidang-bidang pemodelan ini memperhitungkan manfaat kegiatan penggunaan lahan spesifik untuk mengidentifikasi penggunaan lahan pada periode waktu tertentu, dan alokasi tenaga kerja untuk kegiatan-kegiatan yang didasarkan atas ketersediaan rumah tangga dan upah buruh. Model non-spasial ini melaporkan, proporsi bidang-bidang tertentu didasarkan atas kelas penutupan lahan pada setiap periode waktu menggunakan interval waktu 1-tahun, misalnya hutan alam, hutan suksesi sekunder, tanaman permanen, dan padang rumput.

Perbedaan yang dibuat dalam membangun struktur model, didasarkan atas perhitungan besaran dan alokasi per- ubahan. Perhitungan yang didasarkan pada sejumlah faktor pendorong, seberapa besar gerak laju perubahan yang terjadi, sementara model lain hanya mengarah pada lokasi perubahan. Kadang-kadang faktor pendorong yang sama dapat mempengaruhi besaran dan lokasi perubahan. Berdasarkan interpretasi satu atau lebih faktor pendorong, maka faktorfaktor ini menjadi faktor penentu dari lokasi perubahan penggunaan lahan. Hasil proses interpretasi faktor-faktor penggerak perubahan penggunaan lahan ini menghasilkan dengan peta preferensi atau peta preferensi. Peta preferensi dibuat untuk menunjukkan kesesuaian relatif suatu lokasi untuk tipe penggunaan lahan terhadap kesesuaian lokasi lainnya. Faktor pendorong terpilih yang digunakan dalam model atau peta preferensi. Peta preferensi merupakan salah satu komponen utama dari model perubahan penggunaan lahan.

Beragam pendekatan pemodelan yang dijelaskan di atas, mencakup sebagai berikut: (a) sistem berbasis aturan, yang didasarkan atas teori dan penilaian pakar; (b) Peta preferensi berdasarkan analisis empiris; dan (c) aturan transisi bergantung pada penggunaan lahan di lingkungan sekitarnya seperti model cellullar automata. Selain peta preferensi, pola perubahan penggunaan lahan ditentukan oleh persyaratan jenis penggunaan lahan yang berbeda, dan persaingan di antara jenis penggunaan lahan. Oleh karena itu, dalam kebanyakan model, sistem berbasis aturan digunakan untuk mengalokasikan perubahan penggunaan lahan aktual berdasarkan peta preferensi. Aturan-aturan ini bervariasi antara nilai cut-off penggunaan lahan sederhana sampai pemilihan lokasi dengan preferensi tertinggi dari peta preferensi .

\section{Model Dinamis dan Model Statis}

Selain membedakan model berdasarkan representasi spasial, penting juga membedakan kelompok model berdasarkan 
karakteristik temporal. Perhitungan koefisien model regresi menjelaskan distribusi spasial perubahan penggunaan lahan sebagai fungsi dari sejumlah hipotesis faktor pendorong sebagai model statis perubahan penggunaan lahan yang diterapkan secara luas (Chomitz Overmars dan Verburg, 2005). Meskipun model regresi digunakan untuk memprediksi perubahan penggunaan lahan masa depan, tetapi tidak memperhitungkan umpan-balik dalam jalur ketergantungan (path dependencies). Brownet al., (2002) melakukan penelitian mengenai jalur ketergantungan dan validasi model spasial berbasis agen mengenai perubahan penggunaan lahan.

Model dinamis memberikan perhatian khusus terhadap dinamika temporal sistem penggunaan lahan, yang diwakili dengan persaingan antar-jenis penggunaan lahan, dan perubahan ireversibilitas waktu untuk jalur keter-gantungan dalam sistem evolusi dan lintasan statis perubahan penggunaan lahan. Model statis digunakan untuk men-guji faktor-faktor pendorong perubahan penggunaan lahan, sedangkan model di-namis digunakan untuk proyeksi per-ubahan penggunaan lahan masa depan, serta mempelajari lintasan perubahan penggunaan lahan. Model dinamis meliputi sebagian besar model multi-agen dan model eksplisit secara spasial seperti model GEOMOD, model CLUE, mModel SLUTH, dan model SLUDGE.

Menurut Lambin et al., (2000) menyatakan model SLUDGE merupakan model berbasis agen menjelajahi "Eksternalitas (Efek Sampingan) dari laju ekspansi perkotaan di Amerika Serikat, di mana daerah perkotaan dicirikan dengan tingkat kepadatan penduduk dan tingkat fragmentasi penggunaan lahan yang meningkat. Pola seperti ini sering dicirikan sebagai "urban sprawl" dan hipotesis didasarkan atas dampak negatif yang berpengaruh terhadap manusia dan lingkungan secara meluas. Model SLUDGE merupakan model simulasi mengenai ketergantungan penggunaan lahan terhadap eksternalitas pada skala lokal (Simulated Land Use Dependent on Edge-Effect Externalities). Sedangkan model eksplisit secara spasial seperti model berbasis agen (Agent-Based Model), selanjutnya disebut ABM.

Model ABM dirancang untuk mengeksplorasi hipotesis bahwa "eksternalitas (efek sampingan)" mengenai konflik spasial dengan pengurangan nilai dari sebuah lahan cenderung digunakan ketika pembatasan jatah menimbulkan konflik penggunaan lahan, kemudian memberikan kontribusi terhadap pola fragmentasi penggunaan lahan antara perkotaan dan pedesaan, dan menyelidiki implikasi mengenai pola yang terbentuk secara sosial dan ekonomis menjadi tidak efisien (Parker dan Meretsky, 2004). Model ABM pada prinsipnya merupakan teknik pemodelan terbaik untuk memenuhi tujuan ekternalitas lingkungan, karena kemampuan ABM sebagai suatu model interdepensi dan interrelasi antara pilihan-pilihan agen, dampak nilai lahan heterogen, dan umpan-balik antara penggunaan lahan skala makro terhadap pola sewa lahan, dan kekuatan penggerak pada skala mikro dari agen keputusan penggunaan lahan.

Model SLUDGE merupakan model hibrida antara ABM dan Cellular Automata yang beroperasi pada skala lanskap, dan mengalokasikan masing-masing dataset untuk dua penggunaan lahan yang dinilai tinggi. Payoff untuk masing-masing penggunaan lahan bergantung pada pengembalian tetap untuk pertanian, biaya transportasi, eks-ternalitas yang dihasilkan oleh tetangga terdekat, serta nilai endogen yang ditentukan dari sewa lahan perkotaan. Jumlah, lokasi, dan pola penggunaan lahan iteratif, secara bersama-sama ditentukan melalui umpan-balik dari perubahan harga lahan dan penggunaan lahan sekitarnya. Model ini menunjukkan se- 
rangkaian "fakta temuan" sebagai berikut: (a) pola keseimbangan pasar dari fragmentasi penggunaan lahan dapat berada dibawah kondisi optimal; (b) kemungkinan Pareto meningkatkan penataan ulang penggunaan lahan yang mungkin memerlukan koordinasi atau tawar-menawar antar-agen, (c) konflik antara pengguna lahan perkotaan dan perumahan menyebabkan bentuk perkotaan lebih kompak; (d) eksternalitas negatif dari masyarakat perkotaan sampai produsen pertanian menyebabkan perluasan lahan perkotaan tidak efisien secara sosial, dan (e) konflik antara pengguna lahan perkotaan dapat menyebabkan pola fragmentasi pembangunan perkotaan konsisten dengan penetapan perluasan kota yang ada.

\section{Model Deskriptif dan Model Preskriptif}

Model deskriptif bertujuan untuk simulasi fungsional dari sistem penggunaan lahan, dan simulasi eksploratif pola penggunaan lahan jangka pendek. Se-mentara, model preskriptif bertujuan untuk memperhitungkan konfigurasi penggunaan lahan yang sesuai untuk sepe-rangkat tujuan dan maksud penggunaan lahan. Model deskriptif didasarkan pada sistem penggunaan lahan aktual dan proses dominan yang menyebabkan perubahan dalam sistem perubahan penggunaan lahan. Output model memberikan pemahaman mengenai fungsi sistem penggunaan lahan melalui pengujian hipotesis dan analisis interaksi antara entitas level terendah yang berpengaruh terhadap pola penggunaan lahan pada level yang lebih tinggi. Jenis pemodelan ini cocok untuk proyeksi perubahan penggunaan lahan dalam skenario kondisi-kondisi spesifik. Sebagian besar model preskriptif mencakup sistem penggunaan lahan aktual sebagai tantangan untuk konfigurasi penggunaan lahan yang lebih optimal (Lambin et al.,2000).
Tujuan dasar dari sejumlah model preskriptif atau model optimasi adalah bahwa setiap bidang lahan memiliki atribut dan lokasi yang khas, lalu dimodelkan seperti yang digunakan dalam cara yang sesuai dengan serangkaian tujuan yang ditetapkan. Model preskriptif, terutama berguna untuk analisis kebijakan sebagai visualisasi spasial dari pola penggunaan lahan, sehingga merupakan solusi optimal atas kendala dan tujuan preferensi. Model preskriptif tidak memberikan pemahaman dalam lintasan perubahan penggunaan lahan aktual dan kondisi-kondisi yang mungkin diperlukan untuk mencapai situasi yang optimal. Selain itu, banyak model preskriptif mengasumsikan perilaku ekonomi yang optimal oleh pelaku, dan sulit untuk memasukkan perilaku objek yang tidak optimal, misalnya hasil yang berbeda dari nilai, sikap, dan budaya (Rabin, 1998). Sementara, pada tingkat agregat, keterbatasan ini cenderung tidak signifikan, tetapi lebih diperlukan sebagaimana yang terlihat pada skala yang terbaik untuk proses perubahan penggunaan lahan, dan juga penting untuk keanekaragaman antara pelaku (Lambin et al., 2000).

\section{Pendekatan Deduktif dan Pendekatan Induktif}

Perbedaan utama atas sejumlah kelompok model penggunaan lahan adalah peranan dari suatu teori. Sebagian besar model perubahan penggunaan lahan mengandalkan pendekatan induktif, di mana spesifikasi model didasarkan pada korelasi statistik antara perubahan lahan dan kesesuaian variabel penjelas yang memberikan pemahaman atas perubahan ini. Analisis statistik multivariat, probabilitas transisi, dan kalibrasi digunakan untuk mengidentifikasi variabel dan keterkaitannya dalam penerapannya. Pende-katan induktif menjadi populer karena tidak ada teori yang kuat mencakup semua penjelasan perubahan penggunaan lahan dalam memandu 
penelitian-penelitian terkait.

Perkembangan teoritis dalam bidang perubahan penggunaan lahan terhambat oleh interaksi kompleks dari faktor-faktor kausal yang mendasari perbedaan antara skala spasial dan temporal, serta level organisasi yang bekerja secara langsung melalui rute kausal ini. Hal ini mungkin berhubungan dengan dunia ilmiah yang sangat kompleks seperti ekologi, ekonomi, sosiologi, atau geografi. Meta-analisis dari studi kasus mengenai proses-proses aktual yang berlangsung di daerah tertentu sangat bergantung pada konteks dan kondisi spesifik dari suatu daerah atau situs tertentu, dan juga bervariasi dari waktu ke waktu. Interpretasi induktif dari proses penggunaan lahan mendominasi analisis pola spatio-temporal yang cermat dalam pengumpulan data perubahan penggunaan lahan. Oleh karena itu, proses ini sering dilihat sebagai teknik yang paling mudah yang berkaitan dengan kompleksitas. Berbagai jenis model induktif, mulai dari model pengambilan keputusan oleh agen pelaku ditentukan sebagai seperangkat aturan keputusan sampai interaksi hasil observasi untuk pemodelan perubahan penggunaan lahan (Parker et al., 2003).

Hubungan antara pola penggunaan lahan dan variabilitas spasial dalam lingkungan biofisik dan sosio-ekonomi dianalisis dengan teknik statistik regresi (Geoghegan et al., 2001), tetapi teknik empiris lainnya seperti sistem jaringan saraf juga diterapkan (Pijanowski et al., 2005). Catatan penting dari sejumlah penelitian induktif bahwa teori dan pemahaman atas proses pengambilan keputusan digunakan untuk memilih faktor inklusi serta perlu memahami hubungan fungsionalnya. Kuantifikasi hubungan fungsional ini dibangun berdasarkan atas metode induktif.

Peranan penting penelitian model deduktif dalam perubahan penggunaan lahan didasarkan atas teori yang memprediksi pola dari proses-proses perubahan tersebut. Proses yang mendominasi teori atas studi penggunaan lahan memandu karakterisasi dari hubungan pola penggunaan lahan yang dieksplorasi dalam model perubahan lahan. Pendekatan deduktif penting untuk mengeksplorasi beberapa alasan perubahan penggunaan lahan. Identifikasi struktur model dari hubungan kompleks antara lingkungan dan manusia perlu dikaitkan dalam sejumlah teori yang relevan dan fokus pada data yang dibutuhkan untuk mengeksplorasi hubungan tersebut. Pendekatan induktif mengacu pada data yang tersedia (seringkali variabel proksi), tidak sepenuhnya merepresentasi proses-proses yang berlangsung, sehingga memaksa analisis tersebut menghindari peran penting dari proses-proses yang berlangsung.

Penelitian pola perubahan penggunaan lahan cenderung mengeksplorasi proses dan konsep yang menjelaskan pola penggunaan lahan yang diamati (Laney, 2004). Contoh klasik model deduktif perubahan penggunaan lahan didasarkan atas model teori ekonomi Von Thünen. Model deduktif perubahan penggunaan lahan terbaru, disajikan oleh Angelsen (1999), membandingkan empat spesifikasi model yang berbeda berdasarkan pada teori ekonomi perluasan lahan pertanian, dan mengembangkan model teoritis untuk deforestasi dan konversi lahan basah (Walker dan Solecki, 2004).

Model penggunaan lahan eksplisit secara spasial pertama kali diterbitkan Johann Heinrich von Thünen (1783-1850) pada tahun 1826. Pada intinya, model von Thünen menyatakan keadaan terisolasi tentang bag imana sewa lahan ditentukan dengan jarak dari pusat kota, dan persistabilitas dari penggunaan lahan pertanian. Pertimbangan dari model sederhana, bahwa lahan hanya memiliki 2 (dua) kegunaan: pertanian dan hutan. Produksi pertanian per hektar (ha) dari lahan homogen 
yang menghasilkan (y), dan produksi yang terjual di pasar pada harga umum (p). Tenaga kerja dan modal yang diperlukan per ha adalah 1 dan $\mathrm{k}$, dengan harga input $\mathrm{w}$ (upah) dan q (biaya tahunan dari modal), serta biaya trans-portasi per $\mathrm{km}$ adalah $\mathrm{v}$, dan jarak dari pusat pasar d. Model ini mendefinisikan sewa lahan atau keuntungan pertanian (per hektar): $r=p y-w l$ - qk - vd. Sewa lahan menurun ber-dasarkan jarak dan batasan-batasan pertanian, dimana ekspansi per-tanian tidak menguntungkan lagi, yaitu, $r=0$. Jadi pembatasan pada $d=($ py - wl $-q k) / v$.

Model ini menghasilkan beberapa pandangan kritis mengenai penyebab deforestasi secara langsung. Harga output (p) tinggi, dan teknologi produksi (y) meningkat, atau biaya input menurun $(\mathrm{l}, \mathrm{k})$ membuat ekspansi lebih menarik. Biaya modal menurun (q) dalam bentuk akses yang lebih baik untuk kredit dan suku bunga yang lebih rendah menarik pada arah yang sama. Biaya akses berkurang (v) berupa jalan baru atau jalan yang lebih baik, juga memberikan stimulus besar untuk deforestasi. Upah (w) yang tinggi bekerja ke arah yang berlawanan. Kerangka sederhana ini mendorong dilaukan sejumlah penelitian empiris. Angelsen dan Kaimowitz (1999) menemukan konsensus yang luas pada tiga penyebab langsung deforestasi meliputi harga produk pertanian lebih tinggi, banyak jalan baru dan lebih baik, serta rendahnya upah dan kekurangan pekerjaan di luar sektor pertanian.

\section{Model Berbasis Agen dan Piksel}

Agen dicirikan dengan beberapa karakter bahwa agen bersifat otonom, agen terjadi melalui komunikasi dan interaksi dengan lingkungan, dan agen membuat keputusan yang mengikat perilakunya terhadap lingkungan. Sistem multi-agen memberikan penekanan pada proses pengambilan keputusan agen dan organisasi sosial, serta lingkungan di mana individuindividu tersebut berada. Agen tidak selalu seorang individu, tetapi agen dapat mewakili level organisasi seperti kolega, kelompok, desa, dan lain-lain (Parker et al., 2003; Bousquet dan Le Page, 2004). Kelemahan menggunakan agen sebagai unit dasar simulasi adalah kesulitan menghubungkan perilaku agen sampai luas lahan aktual, dan cukup mewakili perilaku spasial (Rindfuss et al., 2004). Oleh karena itu, kedua pendekatan pemodelan memiliki kelemahan dan kelebihan. Pendekatan yang optimal bergantung atas pertanyaan penelitian dan pengembangan model secara spasial dan temporal.

Sejumlah model eksplisit secara spasial, unit analisisnya didasarkan pada luas lahan, baik poligon yang mewakili jalur bidang, plot atau sensus, maupun piksel sebagai bagian dari representasi berbasis raster. Perubahan penggunaan lahan diperhitungkan sebagai objek spasial yang secara langsung menghasilkan pola perubahan penggunaan lahan. Pada level lokal dengan unit analisis plot, bidang, atau lahan pertanian, ada kesesuaian agen perubahan penggunaan lahan, misalnya petani sebagai unit analisis sangat sesuai. Unit analisis disini, sesuai dengan level pengambilan keputusan. Pada level organisasi yang lebih tinggi, individu petani atau pemilik lahan tidak dapat diwakili secara eksplisit, dan simulasi biasanya tidak cocok dengan unit pengambilan keputusan. Akan tetapi, pada kelompok model lain, menggunakan agen individu sebagai unit simulasi juga memadai.

Bousquet et al., (1999) meneliti mengenai sistem multi-agen, pemodelan pendamping dan perubahan penggunaan lahan. Sejak tahun 1994, sekelompok peneliti dari berbagai disiplin ilmu mengembangkan kegiatan pelengkap dengan tema "Simulasi sistem multi-agen (MAS-Multi-Agen System) dan manajemen sumberdaya terbarukan". Isuisu perubahan penggunaan lahan yang terkait 
dengan model ini, yaitu Pertama, pengembangan model abstrak, disebut juga model sosial buatan, yang membantu untuk memahami sifat-sifat generik dari prosesproses yang berinteraksi (Antona et al., 1998); Kedua, pengembangan dari aplikasi model untuk permasalahan konkret dan bersifat lokal untuk memahami dinamika sumberdaya alam terbarukan dan manajemennya (Mathevet et al., 2003); Ketiga, pengembangan platform simulasi (CORMAS-Commonpool Resources and Multi-Agent Systems) (Bousquet et al., 1998); dan Keempat, pengembangan metodologi model pendamping, sebagai alat bantu MAS dalam kerangka pendukung keputusan kolektif yang lebih luas. Model ini disebut "model pendamping" karena digunakan sebagai alat dalam proses mediasi (pendamping pada dimensi sosial) dan berkembang mengikuti proses sosial pada dimensi temporal dan adaptif.

Pendekatan model pendamping merupakan proses interatif berdasarkan proses berulang, berlanjut dan seterusnya sampai tahapan membangun model dan kegiatan lapangan oleh para peneliti. Model yang dikembangkan diperkenalkan sebagai informasi atau ide-ide baru yang diperoleh dari lapangan. Pendekatan ini juga dapat digabungkan dengan metode pengumpulan data dan analisis data lain selama proses pemodelan. Model MAS secara intuitif adalah model yang memainkan peran penting (Role-Playing Game-RPG) dalam simulasi oleh komputer. Bousquet et al.( 1999) mengusulkan untuk mengatur RPG, mirip dengan model MAS, dengan tujuan membantu pemangku kepentingan memainkan peran penting dalam hal sebagai berikut: (1) memahami model dan perbedaan antara model dengan kenyataan, (b) Memvalidasi dan/atau mengusulkan modifi-kasi, dan (c) dapat mengikuti simulasi MAS pada komputer, dan meng- usulkan skenario. Aplikasi model berkisar pada skema irigasi di Senegal dan pertanian di dataran tinggi Vietnam utara. Aplikasi studi kasus di berbagai tempat, pertanyaan ilmiah dan masalah teknis yang baru muncul ditujukan oleh kelompok penelitian.

\section{Model Regional dan Model Global}

Aplikasi model regional penggunaan lahan bervariasi secara luas antara studi kasus lokal mulai beberapa kilometer persegi sampai negara atau benua, dengan tingkat resolusi antara $50 \mathrm{~m}^{2}-1.000 \mathrm{~km}^{2}$. Sejumlah model dikembangkan pada skala ini, contoh aplikasinya sangat beragam. Situasi berbeda untuk model penggunaan lahan yang ber-operasi pada skala benua atau global. Pada skala global hanya beberapa model perubahan penggunaan lahan dikembangkan, dan analisis model global biasanya tidak bertujuan menyelidiki masalah perubahan penggunaan lahan per wilayah, tetapi perubahan peng-gunaan lahan dapat memainkan peran penting dalam analisis perubahan iklim, hilangnya keanekaragaman hayati, produksi pertanian atau pasar internasional. Model global di-tujukan pada kisaran pertanyaan penelitian yang berhu-bungan dengan penggunaan lahan seluruh

Model IAMS (Global Integrated Assessment Models), model penilaian terpadu global merupakan model generasi terbaru yang dikembangkan pada akhir tahun 1980-an dan awal 1990-an dalam menilai isu-isu dan skenario perubahan iklim masa depan sampai dengan produksi pangan dan pertanian. Model ini biasanya terdiri dari sub-komponen yang mewakili populasi. Hal ini terkait dengan kegiatan ekonomi yang mengarah pada permintaan produk pertanian, teknologi, dan faktor lain yang menentukan bagaimana produk ini dipasok, emisi gas radioaktif terkait dengan produksi pertanian, perubahan komposisi atmosfer, dan iklim, serta dampak perubahan iklim terhadap eko-sistem dan kehidupan masyarakat. 
Model IAMS meletakkan kerangka kerja yang kuat dari hasil penelitian sebelumnya. Model ini memainkan peran yang menonjol dalam penilaian perubahan penggunaan lahan terbaru oleh IPCC, Panel intergovernmental tentang Perubahan Iklim (IPCC 2000), Outlook Lingkungan Global (UNEP, 2002), dan skenario perubahan ekologi masa depan yang dihasilkan untuk Penilaian Ekosistem Modern (Millennium Ecosystem Assessment). Model ini juga menonjol dalam penelitian pertanian prospektif, meliputi Lembaga Riset Kebijakan Pangan International (Rosegrant et al., 2002) dan PBB (Fischer et al., 2002). Kelompok model global lain yang membahas dinamika penggunaan lahan adalah model-model ekonomi global. Sebagian besar model-model ekuilibrium, bertujuan untuk menjelaskan alokasi lahan dengan struktur permintaan dan penawaran lahan secara intensif. Contoh model tersebut adalah model IMPACT (Rosegrant et al., 2002) dan model GTAP (Hsin et al., 2004). Model global lain, yang merupakan hasil penelitian Eickhout et al., (2004) mengenai pemodelan penggunaan lahan global yang dipadukan dengan model-model penilaian global, Model IMAGE-2 (Integrated Model to Assess the Global Environment) atau dikenal dengan Model Penilaian Lingkungan Global Terpadu. Model ini adalah model penilaian integratif dalam mensimulasikan konsekuensi lingkungan akibat dari kegiatan manusia di seluruh dunia (Alcamo et al., 1998; Eickhout et al., 2004).

Model IMAGE-2 merupakan interaksi antara sistem sosial, biosfer, dan iklim untuk menilai isu-isu lingkungan seperti perubahan iklim, keanekaragaman hayati, dan kesejahteraan manusia. Tujuan dari model IMAGE-2 adalah untuk mengeksplorasi dinamika perubahan lingkungan global jangka panjang, merepresentasi dari bagaimana sistem bumi bisa berkembang, misalnya penggunaan lahan masa depan sebagai hasil interaksi dari gaya-gaya penggerak seperti demografi, teknologi, ekonomi, sosial, budaya, dan politik. Model ini dirancang untuk membandingkan skenario yang digunakan untuk skenario mitigasi dan adaptasi lingkungan. Perhitungan penggunaan energi dan sosio-ekonomi dilakukan untuk 17 wilayah di dunia. Komponen atmosfer dan laut didasarkan pada pendekatan agregat global. Perhitungan penggunaan lahan dan karbon terestrial dilakukan pada grid berukuran $0,5 \times$ 0,5 , untuk meniru proses detail yang terjadi di alam, dan memberikan pandangan dari konsekuensinya terhadap ekosistem dan kegiatan pertanian.

IMAGE-2 digunakan dalam banyak penelitian untuk mengukur alur proses penelitian yang berbeda dan konsekuensinya terhadap peran penting dalam penilaian global seperti skenario emisi dari IPCC tentang Perubahan Iklim, Outlook lingkungan global UNEP, dan penilaian ekosistem modern (Millennium Ecosystem Assessment). Pada aplikasi terakhir, model IMAGE-2 memberikan pandangan dalam konsekuensi ekonomi dan lingkungan atas empat skenario perdagangan liberalisasi yang berbeda. Liberalisasi dapat membantu dalam memperoleh kesejahteraan, tetapi liberalisasi yang tidak terkoordinasi dapat menyebabkan tekanan berat terhadap lingkungan (Eickhout et al., (2004).

\section{Dimensi Spasial dan Temporal dari Pemodelan Perubahan Penutupan atau Penggunaan Lahan}

Kapasitas model perubahan penggunaan lahan saat ini berhubungan dengan dimensi spasial dan temporal. Isu-isu yang berkaitan dengan dimensi spasial dan temporal disebut sebagai prioritas penelitian dan pemodelan perubahan penggunaan lahan, meliputi skala spasial, interaksi dan autokorelasi spasial, serta dinamika dan umpan-balik temporal (Veldkamp dan Lambin 
2001). Skala model meliputi dimensi spasial, temporal, kuantitatif, atau analitik yang digunakan oleh para ilmuwan untuk mengukur dan mempelajari objek dan proses suatu perubahan (Gibson et al., 2000). Semua skala memiliki luas dan resolusi yang sesuai. Setiap proses penting dari perubahan penggunaan lahan, skala spasial berpengaruh signifikan terhadap pola penggunaan lahan (Dovers, 1995). Seringkali, julat skala spasial merupakan faktor pendorong atas proses-proses yang berkaitan dengan perubahan penggunaan lahan, dan bergerak sesuai dengan level organisasi. Level mengacu pada organisasi dalam sistem hirarki yang terorganisir, misalnya individu, ekosistem, lanskap atau institusi, dan ditandai dengan urutan peringkat dalam sistem hirarki. Interaksi dan umpan-balik antara proses-proses ini terjadi pada berbagai level organisasi.

Pemahaman dan representasi yang jelas dari fungsi sistem penggunaan lahan berlangsung pada skala yang berbeda. Model perubahan penggunaan lahan berperan penting dalam proses perubahan penggunaan lahan. Disiplin ilmu, tradisi, dan pertanyaan penelitian menyebabkan perbedaan dalam skala dan level analisis menangani berbagai model penggunaan lahan. Coleman (1990) mengembangkan sebuah kerangka kerja yang menggambarkan interaksi antara level makro dan mikro untuk sistem sosial yang dapat diterapkan untuk sistem penggunaan lahan. Model perubahan penggunaan lahan sering berdasarkan pada data penginderaan jauh dan GIS pada level regional (makro), sementara pada saat yang sama, model ini mencoba untuk menjelaskan perkembangan tersebut dalam level makro dengan menetapkan mekanisme level mikro. Gambar 1 menyajikan analisis penggunaan lahan pada level makro (jalur A), seringkali didasarkan pada metode empiris, misalnya pemodelan pola spasial penggunaan lahan yang berasal dari proses penginderaan jauh. Jalur B menjelaskan proses-proses yang mendasari dan mengarah pada pola peng-gunaan lahan yang berbeda, misalnya keputusan individu dalam merespon kebijakan penggunaan lahan. Secara bersama-sama, keputusan individu mengarah pada pola perubahan penggunaan lahan yang tidak dapat diprediksi dari kombinasi linear dan hubungan sederhana dari perilaku individu. Aturan lintasan ini, menjelaskan alasan perbedaan pada kondisi mikro dan makro menyebabkan pola penggunaan lahan menjadi berbeda.

Level Makro

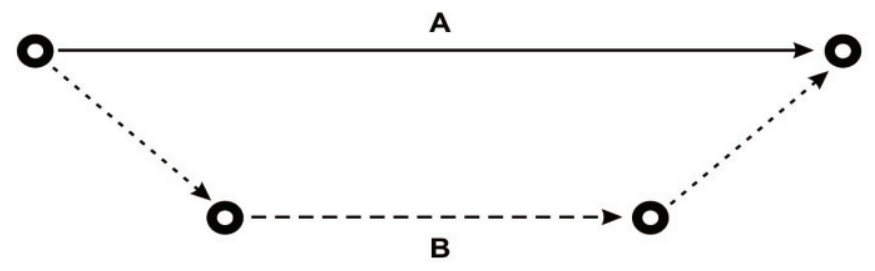

Level Mikro

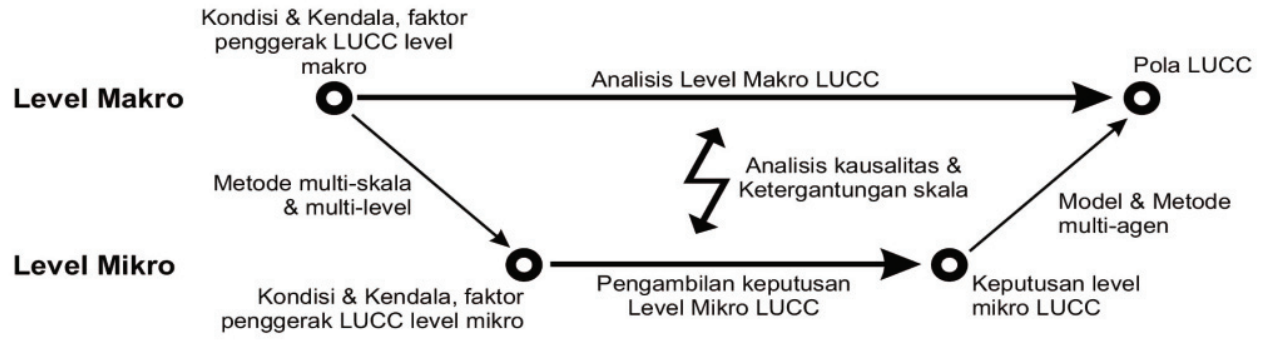

Gambar 1

Hubungan antara penelitian perubahan penggunaan lahan level mikro dan makro (Veldkamp et al., 2004) 
Analisis dinamika level makro dan level mikro menjelaskan perbedaan dalam pendekatan model dan metode analisis yang digunakan. Model perubahan penggunaan lahan terbaru, mengikuti lintasan A dengan menggunakan hubungan antara variabel skala makro untuk simulasi perubahan penggunaan lahan. Pendekatan level makro didasarkan pada analisis struktur spasial penggunaan lahan atau interaksi antara sektor ekonomi. Contohnya, model CLUE (Verburg et al., 1999; Verburg dan Veldkamp 2004), model GEOMOD (Pontius et al., 2001), model LOV (White dan Engelen 2000), dan model LTM (Pijanowski et al., 2002).

Pentingnya isu-isu skala untuk pemodelan perubahan penggunaan lahan dapat diringkas sebagai berikut:

- Penggunaan lahan adalah hasil dari beberapa proses yang berlangsung dalam skala yang berbeda. Pada setiap skala berbeda memiliki pengaruh dominan terhadap proses penggunaan lahan (Turner etal.,1995).

- Agregasi proses skala rinci tidak menyebabkan representasi yang tepat dari proses-proses pada level yang lebih tinggi. Munculnya ketidaklinieritas perilaku kolektif menyebabkan ketergantungan skala menjadi semakin tinggi (Gibson et al., 2000).

- Pengamatan yang berkaitan dengan batas dari resolusi pengukuran biasanya tidak sesuai sampai level tertentu, di mana proses-proses tersebut beroperasi. Hal ini menyebabkan pengamatan hanya secara deskripsi parsial dari seluruh sistem penggunaan lahan multi-skala.

Pendekatan pengukuran multi-skala berhubungan antara penggunaan lahan dan faktor pendorong harus dikenali. Pertama didasarkan pada data grid artifisial dari beberapa resolusi; pada setiap resolusi individu, hubungan antara penggunaan lahan dan faktor pendorong secara statistik ditentukan (Walsh et al., 2001; Braimoh dan Vlek 2004). Kedua, menggunakan statistik multi-level untuk mengeksplorasi faktor pendorong perubahan penggunaan lahan pada kisaran skala tertentu (Goldstein, 1995). Aplikasi pertama dari statistik multi-level digunakan dalam analisis ilmu sosial dari data kinerja pendidikan di sekolah-sekolah (Aitkin et al., 1981). Simulasi dinamika level mikro secara sederhana dalam model yang dibatasi oleh kondisi pada level tinggi. Pendekatan lain memungkinkan interaksi antar-level atau bahkan penggunaan yang berbeda, interaksi model pada level yang berbeda.

Baru-baru ini, pendekatan multi-skala, multi-model diadopsi sebagai metode penting dalam sejumlah proyek skala besar. Contoh kerangka kerja multi-skala adalah model ATEAM (Rounsevell et al., 2005) dan model EURURALIS (Klijn et al., 2005; Verburg et al., 2006). Dalam model EURURALIS, interaksi global menentukan karakteristik produksi dan konsumsi dari daerah yang berbeda, dimodelkan dengan model ekonomi pada skala global berkaitan dengan model-model penilaian integratif untuk menghitung umpanbalik dari perubahan iklim. Alokasi lahan pada skala yang lebih rinci di negara-negara Uni Eropa dilakukan dengan model alokasi lahan eksplisit secara spasial yang menghitung variasi karakteristik biofisik lokasi, sosioekonomi, dan kebijakan. Prosedur ini dipilih karena tidak ada model perubahan penggunaan lahan tunggal yang dapat menjelaskan secara memadai mengenai variasi faktor pendorong yang beroperasi pada skala lokal maupun skala global.

\section{Autokorelasi Spasial dan Interaksi Spasial}

Pola penggunaan lahan hampir selalu menunjukkan hubungan autokorelasi spasial. Penjelasan autokorelasi sebagian besar ditemukan dalam distribusi kelompok dari bentuk dan gradien lanskap pada kondisi 
lingkungan tertentu, yang merupakan determinan penting pola penggunaan lahan. Autokorelasi pola penggunaan lahan secara spasial merupakan interrelasi spasial antara jenis penggunaan lahan itu sendiri, terutama dalam konteks pertumbuhan kota, interaksi lingkungan sekitar berdasarkan pada gagasan bahwa pembangunan kota dipahami sebagai sistem yang mengatur dirinya sendiri, di mana kendala alam dan kontrol institusional seperti kebijakan tata guna lahan merupakan suatu proses pengambilan keputusan lokal yang menghasilkan perkotaan makroskopik.

Walsh et al., (2002) melakukan penelitian mengenai model perubahan penggunaan lahan dalam penelitian interdisipliner, di mana komunitas sains perubahan lahan aktif dalam pemodelan penggunaan lahan dan dinamika penutupan lahan melalui berbagai pendekatan. Pemodelan ini meng-integrasikan faktor-faktor endogen dan eksogen dalam skala ruang dan waktu serta umpan-balik antara manusia, lokasi, dan lingkungan (Walsh dan Kru-Meyer, 2002). Model multilevel atau kombinasi model linier digunakan untuk memperkirakan efek dari variabel level pertanian terhadap pola perubahan penggunaan lahan, dan memperhitungkan pengaruh kontekstual masyarakat untuk setiap lahan pertanian (Pan et al., 2004). Pendekatan pemodelan lainnya, didasarkan atas teori kompleksitas, seperti penggunaan pendekatan cellullar automata (CA) dengan memperhatikan kondisi awal, pertumbuhan, aturan transisi, dan pengaruh lingkungan. Model berbasis agen juga memasukkannya dalam konteks teori kompleksitas dan sistem nonlinier, terdiri dari entitas pengambilan keputusan otonom (agen) dan lingkungan, di mana agen-agen berinteraksi, dan aturan yang mendefinisikan hubungan antara agen dan lingkungannya, serta urutan tindakan dalam model.

Pendekatan pemodelan diperlukan untuk mengkarakterisasi pola perubahan penggunaan lahan yang dinamis dan kompleks. Temuan penting dari model penggunaan lahan di atas, bermanfaat untuk menilai perubahan penggunaan lahan di perbatasan Ekuador utara-Amazon, dengan hasil temuan sebagai berikut: (a) pertumbuhan penduduk yang cepat disebabkan pembagian plot besar, yang pada gilirannya menciptakan lanskap yang lebih kompleks dan terfragmentasi; (b) faktor-faktor kunci yang memprediksi kompleksitas lanskap dari ukuran dan komposisi populasi, fragmentasi lahan, lokasi plot terhadap jalan dan kota, umur plot, kualitas lahan, dan topografi; (c) ukuran dan jumlah keluarga yang memiliki dampak langsung terhadap pembukaan dan penggunaan lahan; (d) penggunaan lahan berkembang dari waktu ke waktu dalam siklus hidup keluarga, dan durasi terhadap plot; (e) program bantuan teknis mengarah untuk penggunaan lahan lebih banyak terhadap tanaman, padang rumput yang kurang, dan total lahan yang dibersihkan kurang; (F) tingkat pendidikan penting dalam menentukan luas dari lahan pertanian; (g) ada korelasi langsung antara jarak ke jalan utama dan pusat kota terhadap pola deforestasi, dan (h) pemukiman penduduk dipengaruhi oleh pola dan proses umpan-balik perubahan penggunaan lahan.

\section{Dinamika Temporal dari Lintasan Umpan- balik dan Perubahan}

Perubahan penggunaan lahan sering tidak linear, tetapi umpan-balik dan ambang batas dalam proses ini memainkan peran penting dalam proses perubahan penggunaan lahan (Turner et al., 2003; Steffen et al., 2004). Pemodelan dinamis dan pembagian periode simulasi menjadi tahapan waktu paling penting. Analisis perubahan penggunaan lahan dapat menjelaskan jalur ketergantungan dari evolusi sistem, memungkinkan beberapa 
kondisi yang stabil dalam lintasan ganda. Perubahan penggunaan lahan tidak hanya dijelaskan sebagai hasil keseimbangan faktor pendorong dari perubahan-perubahan tersebut. Dengan kata lain, perubahan penggunaan lahan bergantung pada kondisi awal yang relatif sederhana. Model automata cellular melakukan hal ini secara eksplisit dalam aturan keputusan yang menentukan probabilitas konversi.

Hasil penelitian Clarke et al., (1996) mengenai model Cellular Automata sebagai alat untuk memasukkan autokorelasi spasial positif. Cellullar Automata (CA) adalah model sederhana yang mensimulasikan, baik perilaku sederhana maupun perilaku kompleks. Model CA didefinisikan oleh (a) grid spasial atau tessellation sel, (b) satu set dari masingmasing keadaan sel grid yang dapat diasumsikan; (c) konfigurasi keadaan awal dari seluruh grid; dan (d) aturan transisi yang didefinisikan antara keadaan sel berdasarkan keadaan wilayah sekitarnya. Perkembangan pesat ilmu komputer, memudahkan model CA dirancang meniru hampir semua konfigurasi spasial dan temporal. Sementara model SLEUTH adalah salah satu dari beberapa pemodelan pertumbuhan perkotaan, dan perubahan penggunaan lahan yang diusulkan (Clarke dan Gaydos, 1998). SLEUTH yang terbaca dalam status layer peta perkotaan pada periode waktu yang berbeda di masa lampau, dan penggunaannya untuk "memandu" sebuah model CA yang kompleks. Model ini memungkinkan modifikasi perubahan yang dibuat sendiri untuk aturan-aturan perilaku yang didasarkan pada seberapa cepat atau lambat sistem berkembang secara keseluruhan. Lebih dari 35 aplikasi SLEUTH untuk kota-kota di seluruh dunia telah dilakukan, dalam berbagai konteks perencanaan yang besar seperti pertumbuhan permukiman informal di Afrika, dan perambahan kota terhadap lokasi pembuangan limbah di Brazil.

Kombinasi dinamika spasial dan temporal sering menyebabkan perilaku yang kompleks dan tidak linear. Akan tetapi, banyak model penggunaan lahan didasarkan pada ekstrapolasi dari tren perubahan tata-guna lahan melalui penggunaan regresi dari perubahan tersebut (Serneels dan Lambin 2001). Oleh karena itu, tipe model ini kurang cocok untuk analisis skenario jangka panjang. Model-model ini hanya berlaku dalam kisaran perubahan penggunaan lahan dalam kurun satu atau dua dekade. Validitas hubungan ini juga bertentangan dengan kondisi kompetitif perubahan antara tipe penggunaan lahan, misalnya perubahan yang disebabkan oleh permintaan lahan yang meningkat. Model ini didasarkan pada analisis struktur (pola) penggunaan lahan, bukan pada perubahan penggunaan lahan, dan dikombinasikan dengan model dinamis dari kompetisi antara tipe penggunaan lahan untuk berbagai aplikasi yang lebih luas.

\section{Kalibrasi dan Validasi Model Perubahan Penggunaan Lahan}

Rykiel (1996) mendefinisikan validasi sebagai "sebuah demonstrasi", yaitu suatu model dengan domain proses aplikasi pada kisaran akurasi yang konsisten untuk aplikasi model preferensi. Validasi model adalah kesepakatan proses pengukuran antara model prediksi dengan data independen. Jika ada kecocokan yang baik, maka metode yang digunakan untuk membuat prediksi dikatakan valid. Hal ini penting untuk membedakan antara kalibrasi model dan validasi model. Kalibrasi mengacu pada proses menciptakan sebuah model sedemikian rupa sehingga konsisten dengan data yang digunakan untuk menciptakan model. Hal ini penting bahwa kumpulan data yang tersedia, sehingga dibagi menjadi dua bagian yang terpisah, disebut data kalibrasi dan data validasi. 
Kalibrasi dan validasi model perubahan penggunaan lahan sebagian besar tidak banyak mendapat perhatian. Hal ini terkait dengan kesulitan memperoleh data yang sesuai untuk kalibrasi dan validasi serta kurangnya metode khusus untuk kalibrasi dan validasi model perubahan penggunaan lahan (Walker, 2003). Dalam beberapa tahun terakhir, banyak metode yang tersedia, baik dikembangkan dalam disiplin lain (Manel et al., 2001) maupun khusus untuk model perubahan penggunaan lahan (Pontius et al., 2004; Visser 2004). Kebingungan tentang validasi model perubahan penggunaan lahan berasal dari perbedaan antara kalibrasi yang cocok dibandingkan validasi yang tidak cocok.

Kesesuaian model empiris, misalnya model regresi yang menghubungkan faktor pendorong dan pola penggunaan lahan yang diamati, hanya pengukuran dari kalibrasi yang cocok, sedangkan kinerja model regresi yang sama memprediksi pola penggunaan lahan dari faktor pendorong dalam lokasi atau periode waktu, yang bisa dianggap sebagai validasi. Jika ada kesesuaian antara model prediksi dan validasi data, maka model dapat membuat ekstrapolasi akurat untuk luasan spasial dan temporal lainnya. Jika karakteristik dan mekanisme dari skala spasial dan temporal mirip dengan karakteristik dan mekanisme yang ada selama fase kalibrasi dan validasi.

Model harus diekstrapolasi untuk luasan tertentu dengan tingkat akurasi yang sama dengan kinerja validasi. Jika model gagal mencapai kesesuaian validasi, maka salah satu harus memiliki derajat kepercayaan dalam kemampuan model untuk peramalan secara akurat. Proses ini harus jelas mengenai mekanisme selama fase kalibrasi dan validasi sampai pada ekstrapolasi karena jika tidak, maka tidak pernah dapat mengetahui tahapan tersebut secara deatil sampai data empiris (Oreskes et al.,
1994). Tidak ada kriteria yang disepakati diantara para ilmuwan mengenai metode dan tingkat kesesuaian yang dianggap "sesuai" antara data validasi dan prediksi model. Pontius (2005), menyarankan bahwa kriteria minimal adalah sesuai. Kesepakatan antara data validasi dan prediksi model oleh para ilmuwan harus lebih sesuai dari kesepakatan antara data validasi dan prediksi dari model nol (null model) (Pontius dan Malanson, 2005).

Pendekatan CLUE adalah model eksplisit secara spasial dari perubahan penggunaan lahan berdasarkan pada pendekatan top-down, mengenai analisis spasial dari pola penggunaan lahan (Verburg et al., 2002). Integrasi model mengarah pada pengembangan dari dua pendekatan pemodelan yang berbeda, membantu dalam mengeksplorasi skenario perubahan penggunaan lahan masa depan. Model multi-agen mengungkapkan interaksi manusia dan lingkungan sekitarnya pada level komunitas (Huigen, 2004), sementara model spasial mengkombinasikan kekuatan penggerak berbasis agen dan pendekatan geografis pada level DAS. Pendekatan pemodelan pertama, toolbox pemodelan menggabungkan teknik multi-agen untuk mengeksplorasi dinamika perubahan penggunaan lahan di daerah tersebut.

Pemodelan dalam konteks metodologi merupakan kerangka analitik untuk menteapkan pilihan dan motivasi pelaku, hubungan interaksi pelaku dengan lingkungan, serta hubungan antara pelaku. Model eksplisit secara spasial dapat menangani proses-proses dinamis, seperti migrasi, perluasan areal pertanian dan perilaku pelaku. Model penelitian berbasis agen menyediakan informasi tentang kausalitas dan proses perubahan penggunaan lahan, dikombinasikan dengan temuan empiris (statistik multivariat), untuk menjelaskan hubungan antara penggunaan lahan dan faktor-faktor penggerak pada level DAS (Overmars dan 
Verburg, 2005). Pemodelan berbasis agen menyediakan hubungan kausal yang kuat, yang menjelaskan temuan empiris. Model simulasi menghasilkan skenario masa depan secara eksplisit spasial. Meskipun pendekatan dan model tersebut di atas, memiliki tujuan yang sama, tetapi pendekatan tersebut menyediakan pemahaman pada level berbeda dan memberikan jenis informasi yang berbeda, serta merupakan instrumen pelengkap untuk target intervensi untuk pem-bangunan berkelanjutan. Pemilihan model sangat bergantung pada pertanyaan penelitian atau kebijakan yang perlu dijawab, sementara isu ketersediaan data juga memainkan peran penting. Tidak ada pendekatan pemodelan yang mampu menjawab semua pertanyaan. Pertanyaan penelitian dapat menimbulkan kemampuan aplikasi dan kesesuaian dari model tertentu dengan skala spasial dan temporal, serta proses perubahan penggunaan lahan yang dominan. Misalnya, model eksplisit spasial seperti model automata selular (Cellullar Automata) mungkin cocok untuk mengeksplorasi dinamika pertumbuhan kota, namun tidak mampu sepenuhnya mengeksplorasi faktor pendorong perubahan lahan pertanian.

Berbagai pilihan model dan pendekatan yang tersedia bagi para peneliti memberi kesempatan untuk memilih pendekatan model yang optimal dengan pertanyaan penelitian sesuai dengan karakteristik daerah studi. Banyak kasus menggunakan berbagai pendekatan model yang tepat untuk mempelajari aspek yang berbeda dari sistem yang diteliti. Ketika model yang digunakan menambah pemahaman dan menguji faktor pendorong perubahan tata guna lahan, kombinasi pendekatan model induktif dan deduktif dapat menambah pemahaman lebih komprehensif. Teknik-teknik induktif dapat digunakan untuk mengeksplorasi data set penelitian dan menyarankan faktor pendorong yang dapat diuji terhadap hubungan kausalitas dalam pendekatan pemodelan deduktif, seperti kombinasi model dan pendekatan yang mengarah pada hubungan langsung antara proses perubahan penggunaan lahan dan pola perubahan yang diamati.

Kepekaan analisis berguna dalam mengidentifikasi mekanisme perubahan penting di daerah tertentu, yang tidak dapat diidentifikasi dari pengamatan lapangan. Dengan demikian pendekatan model dapat dimanfaatkan sebagai alat pembelajaran dan komunikasi antar-peneliti dan pemangku kebijakan lingkungan dalam mengungkap faktor pendorong dan dinamika sistem perubahan penggunaan lahan. Model perubahan penggunaan lahan berperan penting dalam mengeksplorasi perkembangan masa depan yang memungkinkan dalam pengembangan sistem penggunaan lahan secara komprehensif.

\section{DAFTAR PUSTAKA}

Agarwal C, Green GM, Grove JM, Evans TP, Schweik CM (2001) A review and assessment of land use change models: Dynamics of space, time, and human choice. Center for the Study of Institutions, Population, and Environmental Change, Indiana University and USDA Forest Service, Bloomington and South Burlington.

Bockstael NE, Irwin EG (2000) Economics and the land use-environment link. In: Folmer $\mathrm{H}$, Tietenberg $\mathrm{T}$ (eds) The international yearbook of environmental and resource economics 1999/2000. Edward Elgar Publishing, Cheltenham, pp 1-54.

Bousquet F, Le Page C (2004) Multi-agent simulations and ecosystem management: A review. Ecol Model 176:313-332.

Briassoulis H (2000) Analysis of land use 
change: Theoretical and modeling approaches. In: Loveridge S (ed) The web book of regional science at http://www.rri.wvu.edu/regscweb.htm. West Virginia University, Morgantown.

Chomitz KM, Thomas TS (2003) Determinants of land use in Amazonia: A fine-scale spatial analysis. Am J Agric Econ 85:1016-1028.

Evans TP, Manire A, de Castro F, Brondizio E, McCracken S (2001) A dynamic model of household decision-making and parcellevel landcover change in the Eastern Amazon. Ecol Model 143:95-113.

Fischer G, Sun LX (2001) Model based analysis of future land use development in China. Agric Ecosyst Environ 85(13):163-176.

Fischer G, Velthuizen H, Shah M, Nachtergaele F (2002) Global agroecological assessment for agriculture in the 21st century: Methodology and results. International Institute for Applied Systems Analysis and Food and Agriculture Organization, Laxenburg, Austria.

Geoghegan J, Villar SC, Klepeis P, Mendoza PM, Ogneva-Himmelberger $Y$, Chowdhury RR, Turner II BL, Vance C (2001) Modeling tropical deforestation in the southern Yucatán Peninsular region: Comparing survey and satellite data. Agric Ecosyst Environ 85:25-46.

IPCC (Intergovernmental Panel on Climate Change) (2000) Special report on emissions scenarios. Cambridge University Press, Cambridge.

Irwin EG, Bockstael NE (2004) Land use externalities, open space preservation, and urban sprawl. Reg Sci Urban Econ 34:705-725.

Irwin EG, Geoghegan J (2001) Theory, data, methods: Developing spatially-explicit economic models of land use change. Agric Ecosyst Environ 85:7-24.

Kaimowitz D, Angelsen A (1998) Economic models of tropical deforestation: A review. Centre for International Forestry Research, Jakarta, $139 \mathrm{pp}$.

Klijn JA, Vullings LAE, van de Berg $M$, van Meijl $H$, van Lammeren $R$, van Rheenen $T$, Eickhout B, Veldkamp A, Verburg PH, Westhoek H (2005) EURURALIS 1.0: A scenario study on Europe's rural areas to support policy discussion. Background document. Wageningen University and Research Centre/Environmental Assessment Agency (RIVM).

Lambin EF, Baulies X, Bockstael N, Fischer G, Krug T, Leemans R, Moran EF, Rindfuss RR, Sato Y, Skole D, Turner BL II, Vogel C (1999) Land-use and land-cover change (LUCC): Implementation strategy. IGBP Report 48, IHDP Report 10, International Geosphere-Biosphere Programme, International Human Dimensions on Global Environmental Change Programme, Stockholm Bonn, $125 \mathrm{pp}$.

Lambin EF, Rounsevell MDA, Geist HJ (2000) Are agricultural landuse models able to predict changes in land-use intensity? Agric Ecosyst Environ 82:321-331.

Lambin EF, Ehrlich D (1997) Land-cover changes in Sub-Saharan Africa (1982-1991): Application of a change index based on remotely sensed surface temperature and vegetation indices at a continental scale. Remote Sens Environ 61(2):181-200. 
Laney RM (2004) A process-led approach to modeling land change in agricultural landscapes: A case study from Madagascar. Agric Ecosyst Environ 101:135-153.

Millennium Ecosystem Assessment (2005) Ecosystems and human well-being: Synthesis. Island Press, Washington D.C., 137 pp.

Nelson GC, Harris V, Stone SW (2001) Deforestation, land use, and property rights: Empirical evidence from Darien, Panama. Land Econ 77:187-205

Overmars KP, Verburg PH (2005a) Analysis of land use drivers at the watershed and household level: Linking two paradigms at the Philippine forest fringe. Int J Geogr Inf Sci 19:125-152.

Parker DC, Manson SM, Janssen MA, Hoffman M, Deadman P (2003) Multiagent systems for the simulation of land-use and landcover change: $A$ review. Ann Assoc Am Geogr 93:314-337.

Pijanowski BC, Pithadia S, Shellito BA, Alexandridis K (2005) Calibrating a neural network-based urban change model for two metropolitan areas of the upper midwest of the United States. Int J Geogr Inf Sci 19:197-216.

Pontius RG, Cornell JD, Hall CAS (2001) Modeling the spatial pattern of land-use change with GEOMOD2: Application and validation for Costa Rica. Agric Ecosyst Environ 85:191-203.

Rindfuss RR, Walsh SJ, Turner BL II, Fox J, Mishra V (2004b) Developing a science of land change: Challenges and methodological issues. Proc Natl Acad Sci USA 101(39):13976-13981.

Stéphenne N, Lambin EF (2001) A dynamic simulation model of land-use changes in Sudano-sahelian countries of Africa (SALU). Agric Ecosyst Environ 85:145-161.

U.S. EPA (Environmental Protection Agency) (2000) Projecting land-use change: A summary of models for assessing the effects of community growth and change on land-use patterns. U.S. Environmental Protection Agency, Office of Research and Development, Cincinnati.

UNEP (United Nations Environment Programme) (2002) Global environment outlook 3. Past, present and future perspectives. Earthscan, London.

van der Leeuw SE (2004) Why model? Cybernet Syst 35:117-128.

Veldkamp A, Verburg PH (2004) Modeling land use change and environmental impact. J Environ Manage 72(1/2):1-4.

Verburg PH, Veldkamp A (2005) Editorial: Spatial modeling to explore land use dynamics. Int J Geogr InfSci 19:99-102.

Verburg $\mathrm{PH}$, Soepboer W, Limpiada R, Espaldon MVO, Sharifa M, Veldkamp A (2002) Land use change modelling at the regional scale: The CLUE-S model. Environ Manage 30:391-405.

Verburg PH, Veldkamp A (2004) Projecting land use transitions at forest fringes in the Philippines at two spatial scales. Landscape Ecol 19:77-98. 